\title{
Salon
}

\section{〜「楽市フォーラム」提供〜 楽市こぼればなし}

\section{銅板が水に浮くとき！}

恒例の楽市の会，08年 6 月の会合では，増子昇氏の「銅 板が水に浮く」というタイトルの話題提供が行われた。これ はサイエンス・スタジオ・マリー（吉祥瑞枝主宰）が電気化 学会他の後援の下に，今年（2008年）の 4 月 20 日に学士会 館で開いた基礎科学普及活動「キュリー夫人の理科教室」の ために考えた理科実験を披露したものである。

一円玉（重量 $1 \mathrm{~g}$ ）は密度が $2.7 \mathrm{~g} / \mathrm{cm}^{3}$ のアルミニウム製で あり，水に沈む。一度沈んだ一円玉が浮き上がることはない が，そっと水に浮かべると沈まないまま浮かしておくことが できる，という事実もよく知られている，水より密度の大き な金属板が水に浮く原因は「表面張力」にある，という説明 がなされる：しかし，一歩踏み込んで，表面張力がどのよう な㗢きをしたのか，ということまで説明しなければ答えとは 言えない.

「実験 I : 洗面器に水を張り, 厚さ $0.2 \mathrm{~mm}, 10 \mathrm{~cm} \times 10 \mathrm{~cm}$ 正方形の銅板（全重量約 $18 \mathrm{~g}$ ) を水面に静かに置くと銅板 は沈まずに浮いている.この銅板の上に一円玉を順次静かに 載せて行くと14枚 $(14 \mathrm{~g})$ 載せても，すなわち総重量 $32 \mathrm{~g}$ で も沈まない(写真 1 ).」

水の表面張力は約 $73 \mathrm{dyn} / \mathrm{cm}$ であり，長さ $1 \mathrm{~cm}$ 当たり 74 $\mathrm{mg}$ 重の張力を示す．銅板の周囲は $40 \mathrm{~cm}$ であるから，最大 約 $3 \mathrm{~g}$ まで吊り上げることが可能である. 厚さ $0.2 \mathrm{~mm}$ の銅板 の体積は $2 \mathrm{~cm}^{3}$ であるから銅板に働く浮力は $2 \mathrm{~g}$ であり，両

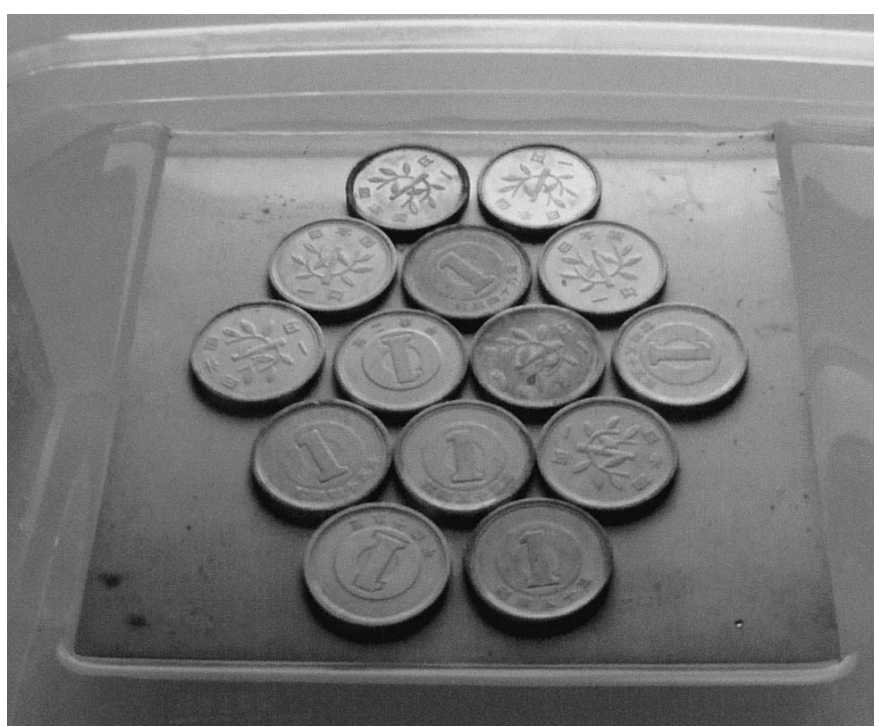

写真1 $10 \mathrm{~cm} \times 10 \mathrm{~cm} \times 0.2 \mathrm{~mm}$ 銅板は, 1 円玉を 14 個載せても 水に沈まない
者を足してもこの銅板を水に浮かしておく力は高々 $4 \mathrm{~g}$ とな り, とても $32 \mathrm{~g}$ を浮かす力はない.

所でよく観察すると, 銅板の上に高さ $3 \mathrm{~mm}$ 程度の水の壁 ができており，見かけ上銅板は高さ $3 \mathrm{~mm}$ の壁で囲まれた， 四角いお盆になっていることがわかる.ヘリの高さが $3 \mathrm{~mm}$ あれば，水の壁で囲まれたお盆の体積は $30 \mathrm{~cm}^{3}$ となり，32 $\mathrm{g}$ の浮力を説明できる、銅板でなく，アルミニウム，ステンレ ス, ニッケル, などの金属薄板を使っても，10 cm×10 cm 正方形では全重量 $32 \mathrm{~g}$ 位までは水に浮く.

「なぜ銅板が水に浮くのか?」しかも「1円玉を何枚も載 せても沈まないほど，実力のある浮き方をするのか？」とい う出題に対して，「アルキメデスの原理による.」とする答え には 100 点満点で 65 点（合格点）をあげられるが，「水の表 面張力の作用による.」「銅板の表面が水に濡れにくい」とい う答えにはそれぞれ 10 点程度しかあげられない。

銅板が水に浮いたのは単純なアルキメデスの原理に基づく, という原理を踏まえた上で，それではアルキメデスの原理が 成り立つための条件がどのようにして造られたのか，が次の 問題となる。

濡れにくい，すなわち表面が疎水性の金属板の上に液体を 置くと，液体の盛り上がった島が出来る。この島の高さは, 液体の密度と表面張力および基板上の接触角で決まる. 写真 2 は銅板上での純水, ドデシル硫酸ソーダ $0.2 \%$ 水溶液，お よび純エタノールのつくる島の様子を示しており, 比較のた めに一円玉を載せてある. この島の高さの理論值を求める式 は，たとえば金原寿郎編，「大学演習物理学（裳華房 1953）：例題 $10 （ \mathrm{p} .65 ） 」 に$ 示されており，この実験の条件 下では $3 \mathrm{~mm}$ 程度の高さは妥当な值である.

水の表面張力は必要条件の一つではあるが，十分条件では ない，基礎科学の普及ということは，科学の考え方を教える ことが目的であり，そのためには，必要条件と十分条件を区 別する論理を意識しておくことが大切になる. せっかくの題

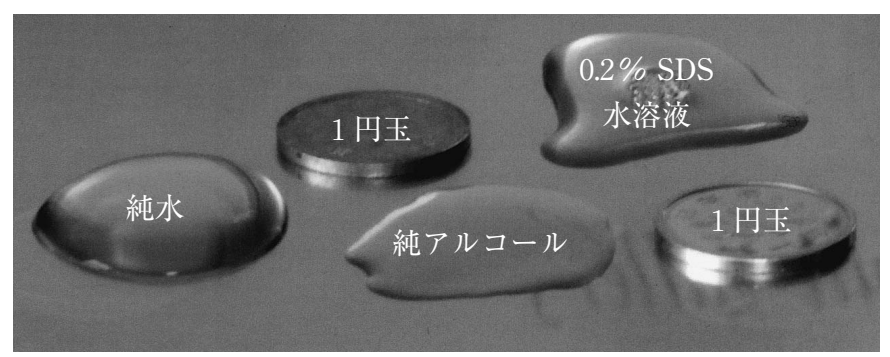

写真2 銅板上にできる水の島 


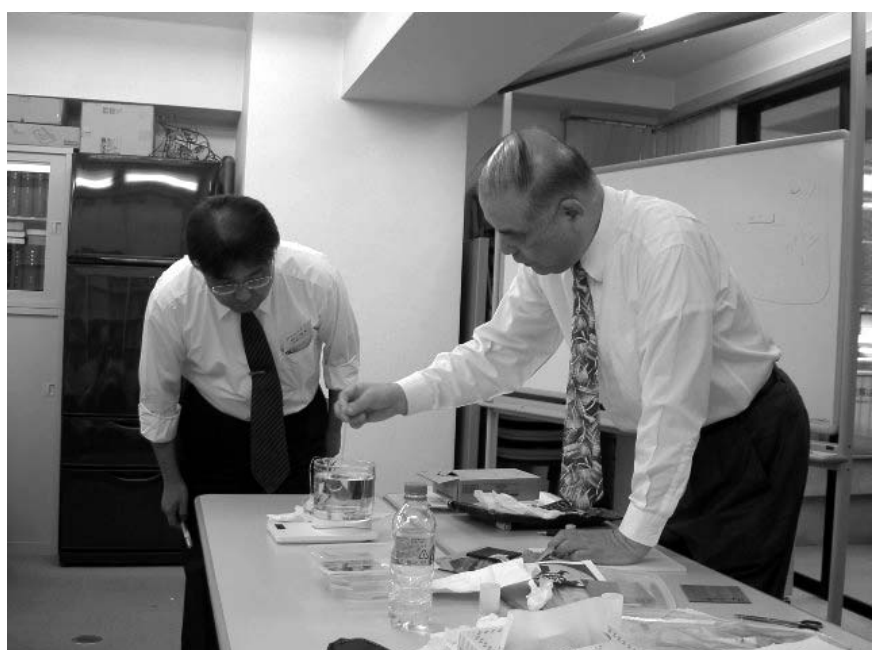

写真3

材を使いながら，「表面張力のせいである」という生半可な 知識を覚えさせるだけでは，かえって害になる。

当時最先端の研究者たちが 1907 年という年に行った, 10 歳前後の自分の子弟に理科の考え方を教えた記録，というも のに基づいて作られた教科書である「キュリー夫人の理科教 室（丸善：2004）」は, 科学というものを「ゆりかご」の時 代から育て上げてきた記憶に根差した，生きた教科書である. 大人になった科学を知識としてとりいれるところから始めた, 科学の伝統を持たない国では，子弟の教育といっても「天下 り式」に知識を覚えこませることしか思いつかない。

この教科書が取り上げている「真空」「空気の重さ」「圧力」 「アルキメデスの原理」「重さ」「体積」「密度」といった言葉 は単なる知識ではなく,「科学思考の基本概念」として子供 の時代に身に付けることが大切である.

さらに「キュリー夫人の理科教室」で取り上げている実験 を，考え方の本質は変えないで，現代の進んだデジタルの道 具を使って実験して見せる，という趣旨で次のような実験が 披露された。

「実験 II : デジタル式上血天秤に容量 $1 \mathrm{~L}$ のポリ・ビーカ

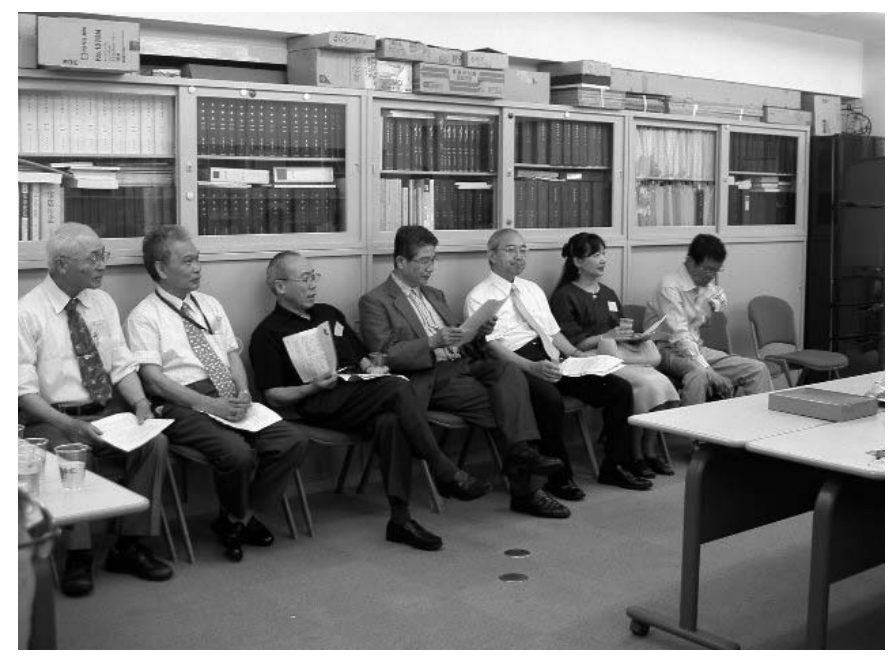

写真4

一を載せ, 水を約 $0.8 \mathrm{~L}$ 入れて風袋重量をリセットする. こ のビーカーの水中に糸で吊った物体を入れる, このとき天秤 の示す数值（A）は水中にある物体の体積を示している. 吊 り糸を切って物体を底に着くように沈めると, その数値（B） は物体の重量である. 両者の比 $\rho=\mathrm{B} / \mathrm{A}$ はこの物体の密度 を表している.」

科学の「ゆりかごの時代の記憶」ということで，森毅氏の 著作から次の言葉を引用する。

「〈重さ〉, 〈体積〉, 〈密度〉などの概念が確立していったの は，17世紀であった。物質の本性を，その物質が空間のあ る部分を占めていること，すなわち〈ひろがり〉においたの はデカルトであったし，それを基礎にして初めて，ニュート ンは〈質量〉を問題にすることができた。

中世からスコラ，ルネッサンス期までは量も質も互いに密 着していて, 重さはまだ明確な量としてとらえられていなか ったと思う。たとえば綿には綿の重さ，鉄には鉄の重さとい うように固有の質について量があった。質を捨象した量とい う発想はきわめて近代的だと言っていい。（森毅「魔術から 数学へ」講談社学術文庫 $996, p .23 \sim) 」$ 